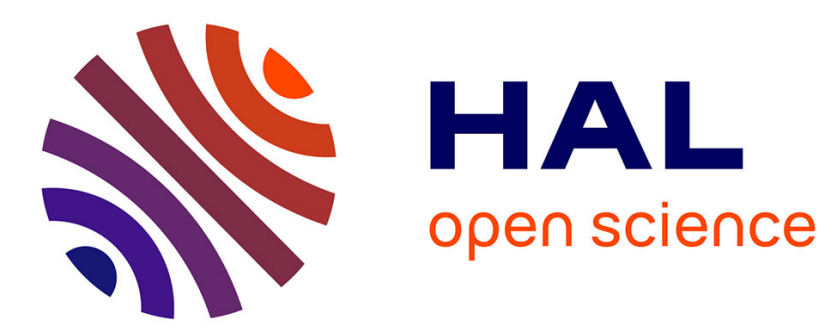

\title{
Fusion of HBsAg and prime/boosting augment Th1 and CTL responses to HCV polytope DNA vaccine.
}

Arash Memarnejadian, Farzin Roohvand

\section{To cite this version:}

Arash Memarnejadian, Farzin Roohvand. Fusion of HBsAg and prime/boosting augment Th1 and CTL responses to HCV polytope DNA vaccine.. Cellular Immunology, 2010, 261 (2), pp.93-8. 10.1016/j.cellimm.2009.11.005 . pasteur-00744908

\section{HAL Id: pasteur-00744908 https://hal-riip.archives-ouvertes.fr/pasteur-00744908}

Submitted on 24 Oct 2012

HAL is a multi-disciplinary open access archive for the deposit and dissemination of scientific research documents, whether they are published or not. The documents may come from teaching and research institutions in France or abroad, or from public or private research centers.
L'archive ouverte pluridisciplinaire HAL, est destinée au dépôt et à la diffusion de documents scientifiques de niveau recherche, publiés ou non, émanant des établissements d'enseignement et de recherche français ou étrangers, des laboratoires publics ou privés. 


\title{
Fusion of HBsAg and prime/boosting augment Th1 and CTL responses to $\mathrm{HCV}$ polytope DNA vaccine
}

\author{
Arash Memarnejadian ${ }^{\mathrm{a}}$ and Farzin Roohvand ${ }^{\mathrm{a} *}$
}

${ }^{\text {a}}$ Hepatitis \& AIDS department-NRGB Laboratory, Pasteur institute of Iran.

*Corresponding Author:

Hepatitis and AIDS Dept., NRGB Laboratory, Pasteur institute of Iran, Pasteur Ave., Tehran 1316943551, Iran

Tel/Fax: +98 2166969291

E-mail: farzin.roohvand@ pasteur.fr

farzin.roohvand@gmail.com 


\section{ABSTRACT}

Correlation of hepatitis $\mathrm{C}$ virus (HCV) spontaneous resolution with $\mathrm{Th} 1$ and $\mathrm{CD} 8^{+} \mathrm{CTL}$ responses during natural infection implies the potentiality of poly-CTL-epitopic HCV vaccines. We recently reported in silico design and construction of DNA vaccines (pcPOLplasmids) harboring HCV CTL-epitopes. Herein, we provide data of mice immunization by pcPOL, (encoding; core ${ }_{132-142}[\mathrm{C}], \mathrm{E} 2_{405-414}\left[\mathrm{E}_{4}\right], \mathrm{E} 2_{614-622}\left[\mathrm{E}_{6}\right]$ and NS3 ${ }_{1406-1415}[\mathrm{~N}] \mathrm{CD} 8^{+} \mathrm{CTL}-$ epitopes as $\mathrm{CE}_{4} \mathrm{E}_{6} \mathrm{~N}$ polytope) and its $\mathrm{HBsAg}$-fused counterpart (pcHPOL), compared to the adjuvant-formulated (Montanide $+\mathrm{CpG}) \quad \mathrm{CE}_{4} \mathrm{E}_{6} \mathrm{~N}$ synthetic-peptide immunization. All vaccinated groups developed different levels of cellular responses, however, only the pcHPOL-immunized mice elicited strong CTLs and IFN- $\gamma$-secreting cells that were further augmented towards a Th1 response and partial tumor protection by DNA-prime/peptideboosting regimen. Priming with $\mathrm{HBsAg}$ alone could not afford its augmenting effect indicating the importance of priming by polytope itself. Hence, fusion of immunocarriers like HBsAg conjoined with DNA-prime/peptide-boost immunization regimen seems a strategy to enhance the epitope-specific immune responses towards poly-CTL-epitopic vaccines.

Keywords: HEPATITIS C VIRUS; POLYTOPE VACCINE; DNA VACCINE; HEPATITIS B SURFACE ANTIGEN; CTL RESPONSE; PRIME/BOOST 


\section{INTRODUCTION}

Hepatitis C virus (HCV), a globally expanding infective virus has already infected 123 million people worldwide [1]. Around 50-85\% of the infected individuals develop chronic disease that may advance to cirrhosis and hepatocellular carcinoma [2]. Despite these alarming rates, no vaccine is available and the only established treatment [ribavirin + interferon (IFN)- $\alpha$ ] is effective in less than $50 \%$ of the patients [3]. HCV has a singlestranded positive-sense RNA genome encoding three structural (core, E1, E2) and six nonstructural (NS) proteins [4]. Due to high mutation rates and generation of quasispecies, neutralizing antibodies targeted against envelope proteins, seem to be insufficient for HCV clearance. In contrast, vigorous and multi-specific $\mathrm{CD} 8^{+}$-cytotoxic T-lymphocyte (CTL)/T helper cell (Th)1 responses as well as high IFN- $\gamma$ levels seem to play a significant role in acute self-limited HCV infection, while are weak or undetectable in chronic state [5;6].

The potency of DNA vaccines to induce CTL responses [7] makes them promising candidates for protection against such viral infections. However, most HCV DNA vaccines failed to elicit protective responses due to the utilization of a complete antigen with limited numbers of dominant CTL epitopes, which are also faced with immune escape through antigenic variation [8]. Besides, presence of suppressive regions within the complete antigen may interfere with the function of dominant epitopes, as shown for structural and NS3 proteins of HCV, resulting in functional subversion of T cells, natural killer and dendritic cells $[5 ; 8 ; 9]$.

Identification of $\mathrm{CD}^{+} \mathrm{CTL}$ epitopes in $\mathrm{HCV}$ antigens has recently provided the opportunity for design of epitope-based immunogens by arranging isolated epitopes in a linear mosaicformat. The advantages of this multi-epitope (Polytope) approach include the co-delivery of multiple conserved and crucial epitopes from various antigens, and preventing deleterious effects encountered with the application of entire proteins [10;11]. Polytope vaccine studies were already described for different tumors and infectious diseases [11] and recently for HCV 
by application of epitopes derived from structural $[9 ; 12]$ and NS [12;13] proteins. However, general drawback of DNA vaccines is their limited potency and generation of low immune responses compared to classical vaccines [7]. This limitation is still more serious in case of epitope-based DNA vaccines, since multiepitope peptides lacking the tertiary structures are usually unstable and sensitive to proteolysis during the expression [13;14]. Thus, polytope DNA vaccines need to be improved for their potency. To this end, different strategies such as prime/boost $[15 ; 16]$ and particle-based immunizations have been employed. Chimeric viruslike particle (VLP)-forming DNA vaccines, which encode viral structural proteins capable of assembling into particulate repeated arrays (such as hepatitis B surface antigen; HBsAg), are recently considered as a promising approach for the efficient delivery of antigenic targets [1719]. This so called "plasmo-VLP" strategy combines the ease of production of plasmid DNA and the improved immunogenicity of VLPs [17]

Recently, we reported the engineering and construction of polytope DNA vaccine plasmids encoding four immunodominant $\mathrm{CD} 8^{+} \mathrm{CTL}$ epitopes derived from both structural and NS antigens of HCV and showed their eligibility by in vitro and primary in vivo analyses [20].

In the present study, we provide a detailed and comparative immunological evaluation in $\mathrm{BALB} / \mathrm{c}$ mice on induction of immune responses against two $\mathrm{H}-2^{\mathrm{d}}$-restricted epitopes incorporated into the same plasmids and further provide evidence that HBsAg fusion and DNA-prime/peptide-boost immunization conjoined to human compatible adjuvants enhance cellular responses and decrease the growth of transfected tumors in challenged mice.

\section{MATERIALS AND METHODS}

\section{Polytope DNA constructs}

In silico design and detailed construction procedure of polytope DNA vaccines exploited in this study, as well as their expression analyses through RT-PCR, dot-blot, Western-blot and immunofluorescence techniques was already described (20). In brief, a polytope DNA 
sequence encoding the H2-D ${ }^{\text {d }}$-restricted epitopes of $\mathrm{C}$ (core ${ }_{132-142}$ : DLMGYIPLVGA) [21] and $\mathrm{E}_{4}\left(\mathrm{E} 2_{405-414}\right.$ : SGPSQKIQLV) [22], besides HLA-A2-restricted epitopes of $\mathrm{E}_{6}\left(\mathrm{E} 2_{614-622}\right.$ : RLWHYPCTI) [23] and N (NS3 ${ }_{1406-1415}$ : KLSGLGLNAV) [24] in the linear $\mathrm{CE}_{4} \mathrm{E}_{6} \mathrm{~N}$ order was codon optimized to support preferred human codon usage (www.kazusa.org.jp/codon/), synthesized by SOEing PCR method and inserted into pcDNA3.1 plasmid (Invitrogen, CA) to provide the pcPOL construct (Fig. 1A). Fusion of $\mathrm{HBsAg}$ gene with $\mathrm{CE}_{4} \mathrm{E}_{6} \mathrm{~N}$ sequence or its insertion as sole HBsAg DNA in pcDNA3.1 provided pcHPOL (Fig. 1B) and control (pcHBs) plasmids, respectively. Of note, the $\mathrm{CE}_{4} \mathrm{E}_{6} \mathrm{~N}$ epitope order was selected as the optimized sequence for both proteasome-mediated epitope processing and reduced junctional epitopes (which can be created by the juxtaposition of two epitopes), based on the results of PAProc (http://paproc.de) and RankPep (http://bio.dfci.harvard.edu/RANKPEP/) modelings, respectively. The potency of particle formation for pcHPOL plasmid was also indirectly assessed through the measurement of HBsAg-based chimeric particles in the supernatant of transfected cells using a commercial HBsAg-ELISA assay (Hepanostika HBsAg Uni-Form II, Biomérieux, France) [20].

\section{Synthetic peptides}

Peptides corresponding to $\mathrm{CD}^{+}$-epitopic peptides $\left(\mathrm{C}, \mathrm{E}_{4}, \mathrm{E}_{6}, \mathrm{~N}\right)$ and an irrelevant $\mathrm{H}-2^{\mathrm{d}}$ restricted epitope (core $16-25$; NRRPQDVKFP), besides the synthetic $\mathrm{CE}_{4} \mathrm{E}_{6} \mathrm{~N}$ long polytopic peptide were synthesized by solid phase Fmoc chemistry with $97 \%$ purity (Institute de Biochimie, Universite de Lausanne, Swiss). In this study, HLA-A2-restricted CD8 ${ }^{+}$-epitopic peptides $\left(\mathrm{E}_{6}\right.$ and $\mathrm{N}$ ) were also used as irrelevant (negative control) peptides for all assays in $\mathrm{BALB} / \mathrm{c}$ mice.

\section{Establishment of CT26/CE $E_{4} E_{6} N$ tumor cells}

BALB/c mouse syngeneic cell line (CT26) was stably transfected with pcPOL plasmid by Lipofectamine LTX reagent (Invitrogen, CA) and cultured under the selection of Geneticin 
(800 $\mu \mathrm{g} / \mathrm{ml})$ for two months. The limiting diluted single clones were screened for the expression of $\mathrm{CE}_{4} \mathrm{E}_{6} \mathrm{~N}$ gene through RT-PCR analysis (data not shown).

\section{Mice and immunization protocols}

Pathogen-free, female BALB/c (H-2 $\left.{ }^{\mathrm{d}}\right)$ mice (6-8 weeks old) were used and handled according to the international animal care ethics. Groups of six mice were immunized sub-cutaneously (s.c.) either in the hind footpad with $50 \mu \mathrm{l}$ of $2 \mathrm{mg} / \mathrm{ml}$ plasmids at weeks 0,3 and 6 , or in the tail base with $100 \mu \mathrm{l}$ of peptide immunogen containing $50 \mu \mathrm{g}$ of $\mathrm{CE}_{4} \mathrm{E}_{6} \mathrm{~N}$ synthetic peptide + $50 \mu \mathrm{g}$ of CpG $1826+70 \%$ Montanide ISA 720 (M720) [25], at days 0, 10 and 20 . Heterologous prime/boost immunization was performed using two DNA injections followed by one peptide administration at 3-week intervals (Table).

\section{Splenocyte isolation}

Two weeks after the last injection, spleens of immunized mice were smashed into a cell homogenizer, washed with phosphate-buffered saline (PBS) and suspended in $0.83 \% \mathrm{NH}_{4} \mathrm{Cl}$ solution for 5 min. to lyse the erythrocytes. After washing with PBS, spleen cells were suspended in complete RPMI-1640 medium, containing 10\% fetal bovine serum (FBS), $2 \mathrm{mM}$ L-glutamine, $100 \mathrm{mg} / \mathrm{ml}$ streptomycin and $100 \mathrm{U} / \mathrm{ml}$ penicillin, to provide single-cell suspension.

\section{In vitro CTL assay}

Single-cell splenocytes $\left(2 \times 10^{6}\right.$ cells $\left./ \mathrm{ml}\right)$ were co-cultured with $\mathrm{C}$ and $\mathrm{E}_{4} \mathrm{CD}^{+}$-epitopicpeptides $\left(10 \mu \mathrm{g} / \mathrm{ml}\right.$ of each) and incubated at $5 \% \mathrm{CO}_{2}, 37{ }^{\circ} \mathrm{C}$ for 4 days, when $10 \mathrm{U} / \mathrm{ml}$ of recombinant IL2 (Cedarlane, Canada) was added to the cultures. On the day 8, the CTLs were recovered by centrifugation, washed with PBS and employed as effector cells in a lactate dehydrogenase (LDH) release assay [25]. Briefly, within the wells of a round-bottom 96-well plate the effector cells were co-cultured with $6 \times 10^{3}$ peptide-pulsed P815 target cells at the effector/target ratios of 50:1, 25:1 and 12.5:1. After $6 \mathrm{~h}$ incubation at $5 \% \mathrm{CO}_{2}, 37{ }^{\circ} \mathrm{C}$, 
supernatants were removed and measured for the release of LDH using Cytotox 96 kit (Promega, WI). The lysis percentage was calculated by the formula; Cytotoxicity $(\%)=$ [(experimental lysis - spontaneous effector lysis - spontaneous target lysis) / (target maximum lysis - target spontaneous lysis) $] \times 100$. Spontaneous release was always $<5 \%$ of the maximum release (lysis with $1 \%$ Triton $\mathrm{X}-100$ ) in all assays. To verify the responding cell type of CTL, blocking of cytotoxicity was carried out. To this end, rat anti-mouse CD4 (BD Pharmingen, Clone GK1.5) and rat anti-mouse CD8 (BD Pharmingen, Clone 53-6.7) monoclonal antibodies were dropped into respective wells of CTL assay (10 $\mu \mathrm{g} / \mathrm{ml})$.

\section{Cytokine release assay}

Single-cell splenocytes $\left(2 \times 10^{6}\right.$ cells $\left./ \mathrm{ml}\right)$ were stimulated with $\mathrm{CE}_{4} \mathrm{E}_{6} \mathrm{~N}$ synthetic peptide (10 $\mu \mathrm{M})$. After $72 \mathrm{~h}$ incubation at $5 \% \mathrm{CO}_{2}$ and $37^{\circ} \mathrm{C}$, supernatants were subjected to analysis of IL4 and IFN- $\gamma$ levels by ELISA (U-CyTech, Netherlands).

\section{Ex vivo Interferone- $\gamma$-ELISpot assay}

IFN- $\gamma$-ELISpot kit (MabTech, Sweden) was used according to the manufacturer's instruction. Briefly, in pre-coated wells $2 \times 10^{5}$ splenocytes were directly incubated with $10 \mathrm{U} / \mathrm{ml}$ of recombinant IL2 and $10 \mu \mathrm{M}$ of $\mathrm{C}, \mathrm{E}_{4}$ or irrelevant $\mathrm{CD}^{+}$-epitopic-peptides or $\mathrm{CE}_{4} \mathrm{E}_{6} \mathrm{~N}$ synthetic peptide for $40 \mathrm{~h}$ at $5 \% \mathrm{CO}_{2}$ and $37{ }^{\circ} \mathrm{C}$. After cell removal, washing steps and antiIFN- $\gamma$ antibody treatments, spot-forming cells (SFCs) were enumerated under a dissection stereoscope (Leica Microscopy system, Heerbrugg, Switzerland).

\section{In vivo tumorigenicity assay}

Three weeks after the last immunization, mice were injected s.c. in the right flank with $2 \times$ $10^{5}$ tumor cells $\left(\mathrm{CT} 26 / \mathrm{CE}_{4} \mathrm{E}_{6} \mathrm{~N}\right)$ in $100 \mu \mathrm{l} \mathrm{PBS}$. Tumor size was measured three times a week with a caliper and the volume was calculated using the formula; width $\times$ length $\times$ (width + length)/2. The pcHBs-primed/CE $\mathrm{CE}_{6} \mathrm{~N}$ peptide-boosted control group was employed to investigate the role of pcHPOL in priming of T cells. 


\section{Statistical analyses}

All experiments were performed in triplicate and/or repeated three times. Prism- 4 software was used for the data handling and statistical analyses were performed using Mann-Whitney nonparametric test and ANOVA. Statistical significance was set at $p<0.05$.

\section{RESULTS}

\section{Cellular responses in immunized mice}

Results of CTL assay indicated a significant increase in specific lysis of $\mathrm{C}_{\mathrm{E}} \mathrm{E}_{4}$ peptide-pulsed P815 target cells by the splenocytes of polytope DNA-vaccinated groups (Table and Fig. 2A, B) compared to the polytope-free pcDNA3.1 and pcHBs injected control counterparts (Fig. 2C, D) and still higher for pcHPOL (specific lysis rate up to $35 \%$ against $\mathrm{E}_{4}$ ) compared to pcPOL (specific lysis rate up to $6 \%$ against $\left.\mathrm{E}_{4}\right)$-immunized mice $(p<0.05)$. In addition, blocking of CTLs with antimouse-CD $8 \mathrm{mAb}$ proved that effector cells were of $\mathrm{CD}^{-} \mathrm{CD} 8^{+}$ type, since only antimouse-CD8 but not antimouse-CD4 could reduce the lysis process up to $10 \%$ (against $\mathrm{E}_{4}$ peptide) in pcHPOL-immunized group (Fig. 2E, F).

Accordingly, results of ex vivo ELISpot assay indicated a significant difference in the number of IFN- $\gamma$-secreting cells in favor of immunized mice (pcPOL and pcHPOL) compared to the control groups and again significantly higher for pcHPOL (both $p<0.05$ ) (Fig. 3A). Absence of detectable responses against irrelevant CTL peptides $\left(\mathrm{H}-2^{\mathrm{d}}\right.$; core $_{16-25}$ and HLA-A2; $\mathrm{E}_{6}$ and N) in both CTL and ELISpot assays indicated the specificity of the responses against HCVspecific $\mathrm{C}, \mathrm{E}_{4}$ and $\mathrm{CE}_{4} \mathrm{E}_{6} \mathrm{~N}$ (IFN- $\gamma$-ELISpot only) peptides. Results of IFN- $\gamma$-ELISpot assay (Fig. 3A and $\mathrm{B}$ ) indicated that cells pulsed with $\mathrm{CE}_{4} \mathrm{E}_{6} \mathrm{~N}$ polypeptide induced more SFCs compared to the cells co-cultured with $\mathrm{C} / \mathrm{E}_{4}$-epitopic peptides. The reason may be due to the activation of both $\mathrm{CD}^{+}$and $\mathrm{CD}^{+}$cells by $\mathrm{CE}_{4} \mathrm{E}_{6} \mathrm{~N}$ polypeptide (40 amino acid residues), while $\mathrm{CD}^{+}$cells were the only source for IFN- $\gamma$ production in case of stimulation with $\mathrm{C} / \mathrm{E}_{4^{-}}$ 
CD8 ${ }^{+}$-epitopic peptides (10-11 amino acid residues), as was consistently verified in our CTL blocking experiment using anti-CD4/CD8 antibodies. In fact, in silico analysis also predicted several $\mathrm{CD}^{+}$and $\mathrm{B}$ cell epitopes in $\mathrm{CE}_{4} \mathrm{E}_{6} \mathrm{~N}$ polypeptide and accordingly antibodies were efficiently raised in rabbits immunized by this polypeptide confirming appearance of B-cell epitopes experimentally [20]. However, $\mathrm{CE}_{4} \mathrm{E}_{6} \mathrm{~N}$ is an artificial sequence assembled from HCV CTL epitopes, which does not occur in natural HCV antigens, therefore, $\mathrm{CD} 8^{+}$-epitopespecific immunity and IFN- $\gamma$ elicited through pulsing by $\mathrm{C} / \mathrm{E}_{4}$ peptides is the major point of interest in our study. Taken together, these results evidenced the proper processing of the $\mathrm{CE}_{4} \mathrm{E}_{6} \mathrm{~N}$ construct towards the induction of the $\mathrm{CD} 8^{+}$-epitope-specific $\mathrm{CTL}$ responses against the incorporated murine epitopes $\left(\mathrm{C}\right.$ and $\left.\mathrm{E}_{4}\right)$ and enhancement of the responses by fusion of HBsAg.

\section{Homologous versus heterologous immunization regimens}

As shown in Fig. 3, splenocytes of mice both primed and boosted with only $\mathrm{CE}_{4} \mathrm{E}_{6} \mathrm{~N}$ peptide + $\mathrm{CpG}+\mathrm{M} 720$ (i.e: no DNA priming) when stimulated with $\mathrm{CE}_{4} \mathrm{E}_{6} \mathrm{~N}$ peptide in vitro, were efficient in both induction of IFN- $\gamma$-producing cells (Table and Fig. 3B) and secretion of IFN$\gamma / \mathrm{IL} 4$ to the culture medium (Fig. 3C). Nevertheless, the lowest number of $\mathrm{C}$ and $\mathrm{E}_{4}$-specific SFCs and the approximately equal levels of IFN- $\gamma /$ IL4 secretion (ratio $~ 1.0$ ) in this group indicated a low epitope-specific and balanced Th1/Th2 response. On the contrary, mice immunized with pcHPOL DNA alone promoted epitope-specific $\left(\mathrm{C}_{\mathrm{E}} \mathrm{E}_{4}\right) \mathrm{IFN}-\boldsymbol{\gamma}$-secreting cells and completely Th1-polarized (IFN- $\gamma /$ IL4 ratio $~ 28: 1$ ) responses albeit in a low level magnitude (Table and Fig. 3B, C).

Interestingly, the heterologous DNA-prime/peptide-boosting approach induced a qualitatively broad Th1 response (IFN- $\gamma / \mathrm{IL} 4$ ratio $~ 3: 1$ ) as well as increased number of C/E 4 -specific SFCs (Table and Fig. 3B, C), compared to the repeated single modality DNA or peptide immunizations. These results indicated the inadequacy of epitope-specific $\mathrm{T}$ cell priming by 
peptide-prime strategy, and suggested for the priming of specific $\mathrm{CD}^{+} \mathrm{T}$ cells and generating the memory Th1 response by DNA (pcHPOL) immunization that was efficiently recalled by adjuvant-formulated polytope peptide boosting.

\section{Tumor Challenge studies}

Viral/tumor challenge studies are considered as a gold standard to evaluate the protective immune responses elicited by a new vaccine candidate [26]. To address this concern, DNAprimed/peptide-boosted mice were challenged with $\mathrm{CE}_{4} \mathrm{E}_{6} \mathrm{~N}$-expressing tumor cells. As shown in Fig. 4, the mice initially primed with pcPOL construct failed to develop the inhibitory response against the growth of $\mathrm{CT} 26 / \mathrm{CE}_{4} \mathrm{E}_{6} \mathrm{~N}$ cells. Interestingly, the mice immunized with pcHBs (polytope-free) control plasmid, but boosted with $\mathrm{CE}_{4} \mathrm{E}_{6} \mathrm{~N}$ peptide also failed to inhibit the tumor growth. This reaffirmed the absolute necessity of polytope DNA priming for the induction of protective immune response. Surprisingly, the pcHPOLvaccinated group significantly reduced the growth of tumor cells at the day 14 post-challenge (Fig. 4), as compared to the control non-immunized and pcHBs-injected groups $(p=0.03$, Mann-Whitney statistical analysis), though it did not induce a complete protection. These results demonstrate that $\mathrm{C}$ and $\mathrm{E}_{4}$-specific CTLs primed by DNA vaccination and boosted with peptide may elicit partial protection only when they are functionally/numerically augmented by the "helping" mechanisms of HBsAg as an immunocarrier.

\section{DISCUSSION}

Multiepitope DNA vaccines may offer a promising approach towards the induction of safer and more effective immunity for highly variable pathogens like $\mathrm{HCV}$, if their immune potencies are improved. Induction of CTL responses against HCV CTL epitopes of core ${ }_{133-142}$ and $\mathrm{E} 1_{315-322}$ by a multiepitope DNA construct in the absence of an obvious source of CD4 ${ }^{+} \mathrm{T}$ cell help was recently shown [9]. However, the results of this prior study implied the need for 
the enhancement of immunogenicity. We addressed this concern through well-defined in silico design and the development of an HBsAg-based plasmo-VLP polytope harboring multiple HCV-derived CTL epitopes in a DNA-prime/peptide-boosting approach. Although intramuscular route is generally used for DNA vaccination, however considering the fewer frequency of antigen presenting cells in muscle than skin [27], we administrated polytope DNA plasmids subcutaneously in the footpad. Of note this route of immunization has been already shown to induce stronger Th1 and CTL responses than muscle [28]. We found that the fusion of HBsAg to the $5^{\prime}$ end of the polytope (in pcHPOL) effectively enhanced the activation of naïve $\mathrm{CD}^{+} \mathrm{T}$ cells and induced heightened $\mathrm{CD} 8^{+}$-epitope-specific $\mathrm{T}$ cell responses (Fig. 2, 3A). It should be noted that, the observed CTL responses in this study might correspond only to $\mathrm{CD}^{+} \mathrm{T}$ cells, because $\mathrm{C}$ and $\mathrm{E}_{4}$ are $\mathrm{CD} 8^{+}$-epitopic peptides of 10-11 amino acid residues (that are not expected to elicit $\mathrm{CD}^{+} \mathrm{T}$ cells) and accordingly, CD4/CD8 blocking experiments also confirmed the correspondence of elicited CTL responses to CD8 ${ }^{+}$ T cells. Besides, in vitro analysis of pcPOL and pcHPOL plasmids by normalized RT-PCR indicated the equal transcription levels for both constructs (data not shown), therefore, it is unlikely that the increased immune responses observed for pcHPOL were the consequence of increased expression. In contrast, these augmented responses may be most likely explained by secretion of HBsAg-based chimeric particles, which allows their efficient uptake and presentation not only to $\mathrm{CD} 4^{+}$but to $\mathrm{CD} 8^{+} \mathrm{T}$ cells by MHC-I molecules via a cross priming pathway [19] and leads to the induction of higher immune responses compared to intracellular or membrane-anchored proteins [29]. Of note, the partial secretion of HBsAg-based particles from Cos-7 cells transfected with pcHPOL plasmid was already reported [20]. However, besides the particle formation, characteristics such as the presence of multiple $\mathrm{T}$ helper epitopes and prolonged expression/secretion properties are other "helping" mechanisms involved in the immunocarrier effects of $\mathrm{HBsAg}[19 ; 30]$ that may explain the augmented 
responses in this study. The inherent immunogenicity of HBsAg for better delivery of $\mathrm{HCV}$ [31;32] and other full-length antigens [18;30] was already described but to our knowledge this is the first report on such an application in a poly-CTL epitope immunogen.

Induction of higher $\mathrm{T}$ cell immunity by pcHPOL construct prompted us to asses the type and magnitude of the generated responses against the $\mathrm{CE}_{4} \mathrm{E}_{6} \mathrm{~N}$ or $\mathrm{C}$ and $\mathrm{E}_{4}$ epitopes in various prime/boost combinations of DNA (pcHPOL), peptide $\left(\mathrm{CE}_{4} \mathrm{E}_{6} \mathrm{~N}\right)$ and DNA/peptide immunization regimens. As shown in Fig. $3 \mathrm{~B}$ and $3 \mathrm{C}$ the mice primed and boosted with pcHPOL DNA alone (i.e: without any peptide boosting) developed relatively low $\mathrm{T}$ cell responses though it was epitope-specific and strongly Th1-biased. This low response despite the presence of HBsAg may be due to the low level antigen expression generally encountered with DNA vaccines [7].

The group immunized only by adjuvant-formulated $\mathrm{CE}_{4} \mathrm{E}_{6} \mathrm{~N}$ polypeptide demonstrated a strong and polytope-specific mixed Th1/Th2 response, but dramatically low against the incorporated $\mathrm{CD}^{+}$epitopes $\left(\mathrm{C}\right.$ and $\left.\mathrm{E}_{4}\right)$. This is consistent with previous observations for incompetence of peptide priming regimen towards the induction of $\mathrm{CD}^{+} \mathrm{T}$ cell responses [16]. Application of human-compatible adjuvant mixture of $\mathrm{CpG} / \mathrm{M} 720$ in protein vaccination has been already shown to result in the induction of either more Th1-biased [33] or mixed Th1/Th2 [25] responses in mice, suggesting for the antigen-dependent role of these adjuvant on the quality of the induced responses. Although the balanced Th1/Th2 response may be generally appreciated as an advantage, however, since polytopes (like $\mathrm{CE}_{4} \mathrm{E}_{6} \mathrm{~N}$ ) are artificial sequences assembled from CTL epitopes, which are not present in natural (HCV) antigens, therefore Th1-biased epitope-specific $\mathrm{CD}^{+}$immunity is the only demanded response. Accordingly, the pcHPOL-primed/CE $\mathrm{E}_{4} \mathrm{E}_{6} \mathrm{~N}$ peptide-boosted group promoted both the highest epitope-specific $\left(\mathrm{CD}^{+}\right)$and Th1-type responses evidenced by IFN- $\gamma$-ELISpot and cytokine secretion assays. Consistently, kinetic studies have also indicated the induction of higher 
$\mathrm{CD}^{+} \mathrm{T}$ cell responses by priming and boosting that utilize alternate antigen presentation pathways [15].

The most encouraging data obtained in our study was the partial regression of $\mathrm{CE}_{4} \mathrm{E}_{6} \mathrm{~N}$ expressing tumor cells in the group immunized with pcHPOL plasmid and boosted with $\mathrm{CE}_{4} \mathrm{E}_{6} \mathrm{~N}$ peptide (Fig. 4). This inhibition of tumorigenicity was not observed in the case of pcPOL-injected mice, despite employing the DNA-prime/peptide-boosting regimen. The reason behind this observation may be the lack of $\mathrm{CD}^{+} \mathrm{T}$ cell help in construct containing only $\mathrm{CD}^{+} \mathrm{CTL}$ epitopes. This is in further agreement with recent claims for the inevitable requirement of $\mathrm{CD}^{+} \mathrm{T}$ cells to the help of $\mathrm{CD} 4^{+}$cells for efficient protection against $\mathrm{HCV}$ [5]. Our results in conjunction with similar observations $[11 ; 14]$ also propounded that the antigen used for CD4 stimulation needs not necessarily be of a cognate source related to the pathogen itself, as HBsAg was successfully employed for such a goal in case of $\mathrm{HCV}$ polytope construct in our study. In fact, bystander activation of $\mathrm{T}$ cells (e.g. epitope nonspecific $\mathrm{T}$ cell activation) either by cytokines acting independently of $\mathrm{T}$ cell receptor or by $\mathrm{T}$ cell receptor cross reactivity with HBsAg epitopes may be countered for augmenting immunogenicity [34]. Therefore, besides the particle formation and antigen presenting cell targeting by $\mathrm{HBsAg}$, bystander activation of $\mathrm{T}$ cells may be another possible explanation for augmenting immunogenicity in case of pcHPOL. Hence, activated HBsAg-specific effector cell populations may influence the strength and quality of HCV epitope-specific cellular immune responses by cytokines. Accordingly, immunization with HBsAg plasmid DNA was previously shown to evoke Th1 cytokines probably due to the HBsAg-specific helper epitopes [19]. This observation is also consistent with the increased secretion of IFN- $\gamma$ in pcHPOL immunized mice of our study compared to the group vaccinated with pcPOL plasmid, without any significant change in IL4 secretion (data not shown). 
In summary, herein, we described a novel synthetic polytope arrangement based on four immunodominant murine and human-restricted CTL epitopes derived from HCV structural and NS antigens and demonstrated the eliciting of $\mathrm{CD}^{+}$responses towards the $\mathrm{H}-2^{\mathrm{d}}$ epitopes in $\mathrm{BALB} / \mathrm{c}$ mice. Although this construct still needs more optimizations in respect of its efficiency, however, our findings indicated the potency of HBsAg-based plasmo-VLP and DNA-prime/peptide-boosting in human-compatible adjuvants (Montanide $+\mathrm{CpG}$ ) as a combined promising strategy for the improvement of multi-CTL epitope vaccines, in the absence of cognate $\mathrm{CD}^{+}$epitopes. These results provide enough motivations to warrant further preclinical studies towards the analysis of $\mathrm{T}$ cell responses against the HLA-A2restricted incorporated epitopes $\left(\mathrm{E}_{6}\right.$ and $\left.\mathrm{N}\right)$ in HLA-transgenic mice and challenge studies by the application of recombinant viral vectors harboring HCV antigens.

\section{ACKNOWLEDGEMENTS}

A.M received a fellowship from graduate school of Institut Pasteur to pursue this study in the Ph.D. program. Portions of this study were presented as oral presentations in symposium of Research on Infectious Diseases- A Global Challenge (26-27 June 2008, Paris) and first international vaccine congress (9-11 December 2007, Amsterdam). 


\section{REFERENCES}

[1] C. W. Shepard, L. Finelli, M. J. Alter, Global epidemiology of hepatitis C virus infection, Lancet Infect. Dis. 5 (2005) 558-67.

[2] J. M. Pawlotsky, Hepatitis: HCV variability, the immune system and resistance to antiviral drugs, Nat. Rev Gastroenterol. Hepatol. 6 (2009) 383-385.

[3] D. Moradpour, V. Brass, R. Gosert, B. Wolk, H. E. Blum, Hepatitis C: molecular virology and antiviral targets, Trends Mol. Med. 8 (2002) 476-482.

[4] F. Penin, Structural biology of hepatitis C virus, Clin. Liver Dis. 7 (2003) 1-21.

[5] L. B. Dustin, C. M. Rice, Flying under the rader: the immunobiology of hepatitis C, Annu. Rev. Immunol. 25 (2007) 71-99.

[6] B. Rehermann, M. Nascimbeni, Immunology of hepatitis B virus and hepatitis C virus infection, Nat. Rev. Immunol. 5 (2005) 215-229.

[7] S. Gurunathan, M. D. Klinman, A. R. Seder, DNA vaccines: immunology, application and optimization, Annu. Rev. Immunol. 18 (2000) 927-974.

[8] P. Sarobe, J. J. Lasarte, N. Casares, C. A. Lopez-Diaz de, E. Baixeras, P. Labarga, N. Garcia, F. Borràs-Cuesta, J. Prieto, Abnormal priming of CD4(+) T-cells by dendritic cells expressing hepatitis C virus core and E1 proteins, J. Virol. 76 (2002) 5062-5070.

[9] L. Shi, S. Liu, G. Fan, L. Sheng, H. Ren, Y. Yuan, Effective induction of type-1 cytotoxic T-cell responses in mice with DNA vaccine encoding two hepatitis $\mathrm{C}$ virus cytotoxic T-lymphocyte epitopes, Viral Immunol. 19 (2006) 702-711. 
[10] A. Sette, B. Livingston, D. McKinney, E. Appella, J. Fikes, J. Sidney, M. Newman, R. Chesnut, The development of multi-epitope vaccines: epitope identification, vaccine design and clinical evaluation, Biologicals 29 (2001) 271-276.

[11] A. Suhrbier, Polytope vaccines for the co-delivery of multiple CD8 T-cell epitopes, Expert Rev. Vaccines 1 (2002) 207-213.

[12] L. Chen, T. Gao, N. Yang, J. Huang, Y. Chen, T. Gao, Q. Li, D. Ren, Immunization with a synthetic multiepitope antigen induces humoral and cellular immune responses to hepatitis C virus in mice, Viral Immunol. 20 (2007) 170-179.

[13] P. Martin, B. Simon, Y. C. Lone, L. Chatel, R. Barry, G. Inchauspé, A. Fournillier, A vector-based minigene vaccine approach results in strong induction of T-cell responses specific of hepatitis C virus, Vaccine 26 (2008) 2471-2481.

[14] T. Woodberry, J. Gardner, L. Mateo, D. Eisen, J. Medveczky, I. A. Ramshaw, S. A. Thomson, R. A. Ffrench, S. L. Elliott, H. Firat, F. A. Lemonnier, A. Suhrbier, Immunogenicity of a human immunodeficiency virus (HIV) polytope vaccine containing multiple HLA-A2 HIV CD8+ cytotoxic T-cell epitopes., J. Virol. 73 (1999) $5320-5325$.

[15] J. N. Radcliffe, J. S. Roddick, P. S. Friedmann, F. K. Stevenson, S. M. Thirdborough, Prime-boost with alternating DNA vaccines designed to engage different antigen presentation pathways generates high frequencies of peptide-specific CD8+ T cells, J. Immunol. 177 (2006) 6626-6633.

[16] H. Jin, Y. Kang, C. Xiao, K. Zhu, Y. Ma, Q. Xie, J. Ma, Q. Xie, C. He, Z. Yang, Z. Sun, X. Zhang, M. Chen, F. Zhang, B. Wang, DNA-prime followed by protein-boost 
enhances neutralization and Th1-type immunity against FMDV, Viral Immunol. 18 (2005) 539-548.

[17] B. Bellier, C. Delba, B. Clerc, D. Desjardins, R. Drury, F. Cosset, M. Collins, D. Klatzmann, DNA vaccines encoding retrovirus-based virus-like particles induce efficient immune responses without adjuvant, Vaccine 24 (2006) 2643-2655.

[18] D. Marsac, A. L. Puaux, Y. Riviere, M. L. Michel, In vivo induction of cellular and humoral immune responses by hybrid DNA vectors encoding simian/human immunodeficiency virus/hepatitis B surface antigen virus particles in BALB/c and HLA-A2-transgenic mice, Immunobiology 210 (2005) 305-319.

[19] W. P. Woo, T. Doan, K. Herd, H. J. Netter, R. Tindle, Hepatitis B surface antigen vector delivers protective cytotoxic T-lymphocyte responses to disease-relevant foreign epitopes, J. Virol. 80 (2006) 3975-3984.

[20] A. Memarnejadian, F. Roohvand, A. Arashkia, S. Rafati, M. A. Shokrgozar, Polytope DNA vaccine development against hepatitis C virus: A streamlined approach from in silico design to in vitro and primary in vivo analyses in BALB/c mice, Protein Pept. Lett. 16 (2009) 842-850.

[21] H. F. Lohr, D. Schmitz, M. Arenz, S. Weyer, G. Gerken, K. H. Meyer zum Büschenfelde, The viral clearance in interferon-treated chronic hepatitis $\mathrm{C}$ is associated with increased cytotoxic T-cell frequencies, J. Hepatol. 31 (1999) 407-415.

[22] S. H. Park, S. H. Yang, C. G. Lee, J. W. Youn, J. Chang, Y. C. Sung, Efficient induction of $\mathrm{T}$ helper-1 CD4+ T-cell responses to hepatitis $\mathrm{C}$ virus core and $\mathrm{E} 2$ by a DNA prime-adenovirus boost, Vaccine 21 (2003) 4555-4564. 
[23] P. Sarobe, E. Huarte, J. J. Lasarte, L. de Cerio, N. Garcia, F. Borràs-Cuesta, J. Prieto, Characterization of an immunologically conserved epitope from hepatitis C virus E2 glycoprotein recognized by HLA-A2-restricted cytotoxic T-lymphocytes, J. Hepatol. 34 (2001) 321-329.

[24] R. Thimme, D. Oldach, K. M. Chang, C. Steiger, S. C. Ray, F. V. Chisari, Determinants of viral clearance and persistence during acute hepatitis $\mathrm{C}$ virus infection, J. Exp. Med. 194 (2001) 1395-1406.

[25] F. Roohvand, M. R. Aghasadeghi, S. M. Sadat, A. Budkowska, A. R. Khabiri, HCV core protein immunization with Montanide/CpG elicits strong Th1/Th2 and long-lived CTL responses, Biochem. Biophys. Res. Commun. 354 (2007) 641-649.

[26] K. Shinoda, K. Q. Xin, N. Jounai, Y. Kojima, Y. Tamura, E. Okada, S. Kawamoto, K. Okuda, D. Klinnman, K. Okuda, Polygene DNA vaccine induces a high level of protective effect against HIV-vaccinia virus challenge in mice, Vaccine 22 (2004) 3676-3690.

[27] E. Sprecher, Y. Becker, Herpes simplex virus type 1 pathogenicity in footpad and ear skin of mice depends on langerhans cell density, mouse genetics, and virus strain, J. Virol. 61 (1987) 2515-2522.

[28] M. Jazayeri, H. Soleimanjahi, F. Fotouhi, N. Pakravan, Comparison of intramuscular and footpad subcutaneous immunization with DNA vaccine encoding HSV-gD2 in mice, Comp. Immunol. Microbiol. Infect. Dis. 32 (2009) 453-461.

[29] J. S. Boyle, C. Koniaras, A. M. Lew, Influence of cellular location of expressed antigen on the efficacy of DNA vaccination: cytotoxic T-lymphocyte and antibody 
responses are suboptimal when antigen is cytoplasmic after intramuscular DNA immunization, Int. Immunol. 9 (1997) 1897-1906.

[30] A. Baez-Astua, E. Herraez-Hernandez, N. Garbi, H. A. Pasolli, V. Juarez, H. H. Zur, A. Cid-Arregui, Low-dose adenovirus vaccine encoding chimeric hepatitis B virus surface antigen-human papillomavirus type-16 E7 proteins induces enhanced E7specific antibody and cytotoxic T-cell responses, J. Virol. 79 (2005) 12807-12817.

[31] J. Jin, J. Yang, J. Liu, Y. Kong, Y. Wang, G. Li, DNA immunization with fusion genes encoding different regions of hepatitis C virus E2 fused to the gene for hepatitis B surface antigen elicits immune responses to both HCV and HBV, World J. Gastroenterol. 8 (2002) 505-510.

[32] H. J. Netter, T. B. Macnaughton, W. P. Woo, R. Tindle, Antigenicity and immunogenicity of novel chimeric hepatitis B surface antigen particles with exposed hepatitis C virus epitopes, J. Virol. 75 (2001) 2130-2141.

[33] Q. Qiu, R. Y. Wang, X. Jiao, B. Jin, F. Sugauchi, T. Grandinetti, H. J. Alter, J. W. Shih, Induction of multispecific Th-1 type immune response against HCV in mice by protein immunization using $\mathrm{CpG}$ and Montanide ISA 720 as adjuvants, Vaccine 26 (2008) 5527-5534.

[34] R. M. Welsh, J. M. McNally, M. A. Brehm, L. K. Selin, Consequences of crossreactive and bystander CTL responses during viral infections, Virology 270 (2000) 48. 


\section{FIGURE LEGENDS}

FIGURE 1. Schematic presentation of domain structures of intact (A) and HBsAg-fused (B) polytope $\left(\mathrm{CE}_{4} \mathrm{E}_{6} \mathrm{~N}\right)$ sequences cloned in pcDNA3.1 (pcPOL and pcHPOL, respectively). HindIII, BamHI and EcoRI are the employed cloning sites. The four blocks of the core $132-142$, $\mathrm{E} 2_{405-414}, \mathrm{E} 2_{614-622}$ and $\mathrm{NS} 3_{1406-1415}$ epitopes represent the corresponding amino acid sequences related to the specified epitopes. HBsAg fusion gene is shown as a separate block in pcHPOL plasmid.

FIGURE 2. Epitope-specific CTL induction by polytope DNA immunization. Pooled splenocytes from mice (6/group) immunized with pcPOL (A), pcHPOL (B), or control vectors; pcDNA3.1 (C) and pcHBs (D) plasmids in different groups were in vitro restimulated with $\mathrm{CD}^{+}$-epitopic peptides $\left(\mathrm{C}\right.$ and $\left.\mathrm{E}_{4}\right)$ for 8 days and tested against P815 target cells pulsed with either $\mathrm{C}$ or $\mathrm{E}_{4}$ or irrelevant peptides in different effector/target $(\mathrm{E} / \mathrm{T})$ ratios using $\mathrm{LDH}$ based cytotoxicity assay. HLA-A2 $\left(\mathrm{E}_{6}\right.$ and $\left.\mathrm{N}\right)$ and $\mathrm{H}-2^{\mathrm{d}}\left(\mathrm{core}_{16-25}\right)$-restricted $\mathrm{CD} 8^{+}$-epitopic peptides were used as irrelevant peptide for CTL assays in this study. Specific lysis percent in pcPOL and pcHPOL vaccinated groups was significantly higher than control groups and still higher in pcHPOL immunized mice. While anti-CD4 antibody did not significantly affect the CTL activity (E), it was blocked by anti-CD8 monoclonal antibody (F), indicating that the CTL effector cells were of $\mathrm{CD}^{-} \mathrm{CD}^{+}$phenotype (only data corresponding to $\mathrm{E}_{4}$-specific CTLs in pcHPOL-immunized group are shown). Data points are means \pm SD of triplicate wells and statistical analyses are performed by Mann-Whitney nonparametric test.

FIGURE 3. Type and magnitude of cellular responses induced in polytope-immunized mice. (A) Splenocytes from individual mice immunized with pcPOL, pcHPOL or control vectors (pcDNA3.1 and pcHBs) were stimulated with either $\mathrm{H}-2^{\mathrm{d}}$ epitopes $\left(\mathrm{C}\right.$ and $\left.\mathrm{E}_{4}\right)$ or $\mathrm{CE}_{4} \mathrm{E}_{6} \mathrm{~N}$ 
polytope peptide or an irrelevant peptide in three different reactions and IFN- $\gamma$-secreting splenocytes (SFCs) were quantified in ELISpot assay. (B) Mice were immunized in three different regimens with either pcHPOL (DNA) or $\mathrm{CE}_{4} \mathrm{E}_{6} \mathrm{~N}$ synthetic peptide formulated in $\mathrm{M} 720+\mathrm{CpG}$ (Peptide) or a combination of these two (DNA-prime/Peptide-boost) and SFCs related to individual mice were quantified in ELISpot assay. (C) Splenocytes of individual mice immunized in three different regimens (panel B) were stimulated with $\mathrm{CE}_{4} \mathrm{E}_{6} \mathrm{~N}$ synthetic peptide and the levels of IFN- $\gamma$ and IL4 secretion to the culture media were quantified by ELISA. . HLA-A2 ( $\mathrm{E}_{6}$ and $\left.\mathrm{N}\right)$ and $\mathrm{H}-2^{\mathrm{d}}\left(\mathrm{core}_{16-25}\right)$-restricted $\mathrm{CD} 8^{+}$-epitopic peptides were used as irrelevant peptides for ELISpot assays in this study. Data are expressed as means \pm standard errors per groups and $*$ indicates the significant differences $(p<0.05)$ according to Mann-Whitney nonparametric (A) and ANOVA (B and C) analyses.

FIGURE 4. Tumor challenge of the mice vaccinated with polytope constructs in heterologous prime/boost regimen. Non-immunized (NI) or DNA-prime/Peptide-boost immunized mice (two DNA injections with either pcPOL or pcHPOL or control vector; pcHBs followed by one adjuvant-formulated $\mathrm{CE}_{4} \mathrm{E}_{6} \mathrm{~N}$ peptide boost) received $2 \times 10^{5} \mathrm{CE}_{4} \mathrm{E}_{6} \mathrm{~N}$-expressing $\mathrm{CT} 26$ tumor cells sub-cutaneously. Results, representing the tumor volumes at the indicated time points, show the significant regression of tumor growth in the pcHPOL-primed group in comparison with the NI or pcHBs-primed group, at the day 14 post-inoculation $(p=0.03$, Mann-Whitney nonparametric statistical analysis) and afterwards. Data are expressed as means \pm standard errors per group and $*$ indicates the significant differences $(p<0.05)$. 
HindIII

BamHI

EcoRI

\begin{tabular}{|c|c|c|c|c|}
\hline & core $_{132-142}$ & $\mathrm{E} 2_{405-414}$ & $\mathrm{E} 2_{614-622}$ & $\mathrm{NS3}_{1406-1415}$ \\
\hline & DLMGYIPLVGA & SGPSQKIQLV & RLWHYPCTI & KLSGLGLNAV \\
\hline HBsAg & DLMGYIPLVGA & SGPSQKIQLV & RLWHYPCTI & KLSGLGLNAV \\
\hline
\end{tabular}

(A)

(B) 
(A) pcPOL

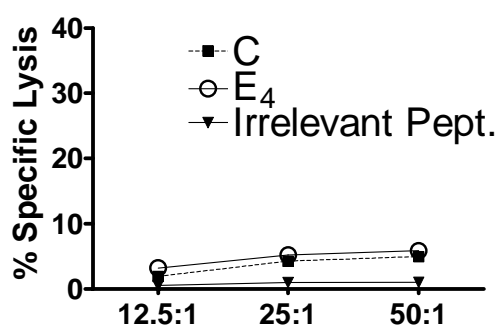

(C)

pcDNA3.1

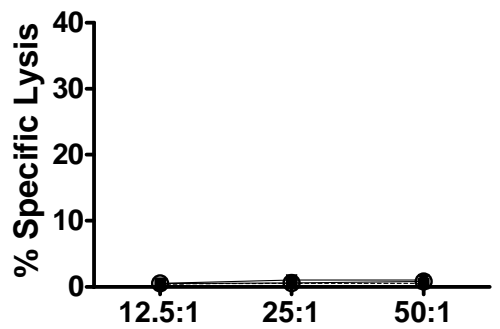

(E) pcHPOL+ Anti CD4

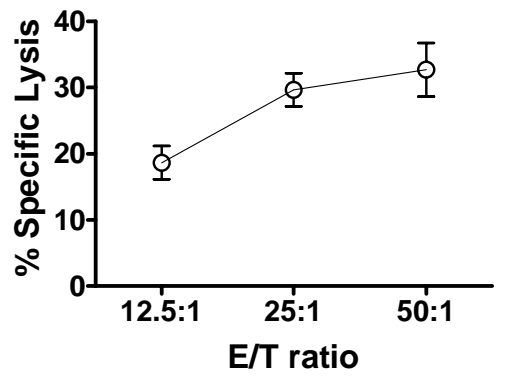

(B) pcHPOL

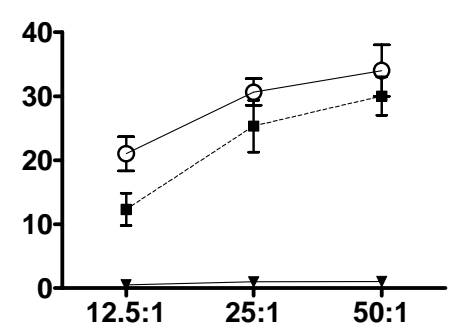

(D) pcHBs

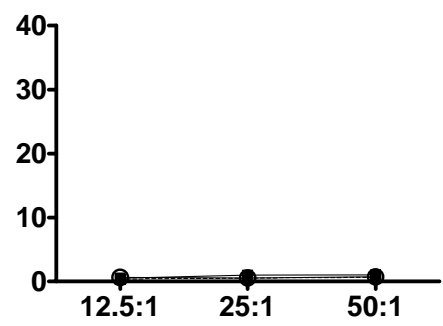

(F) pcHPOL+Anti CD8

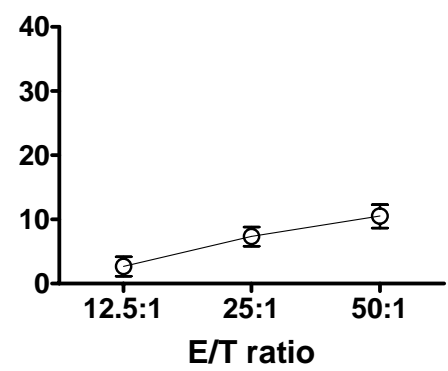



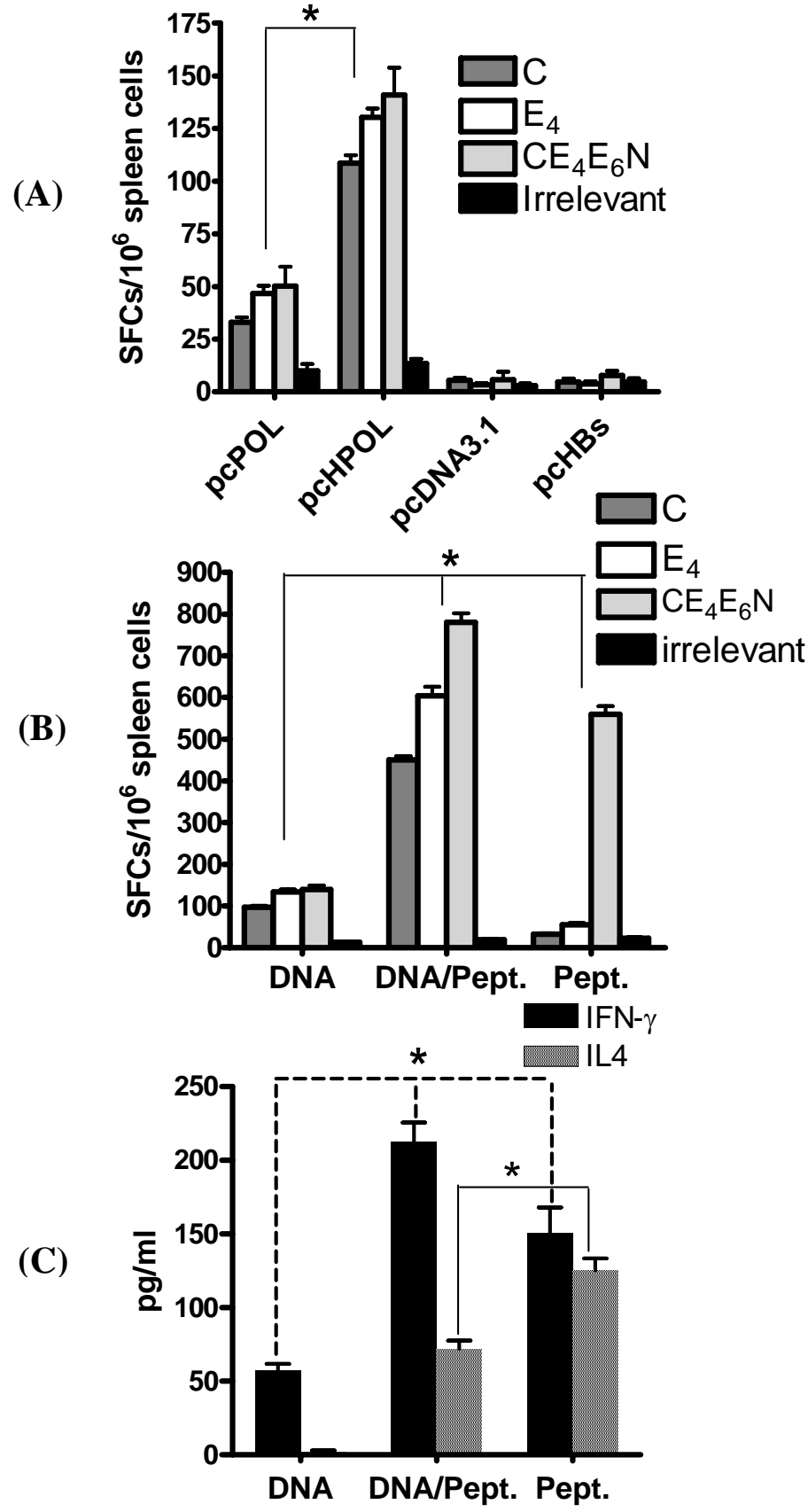
Figure 4

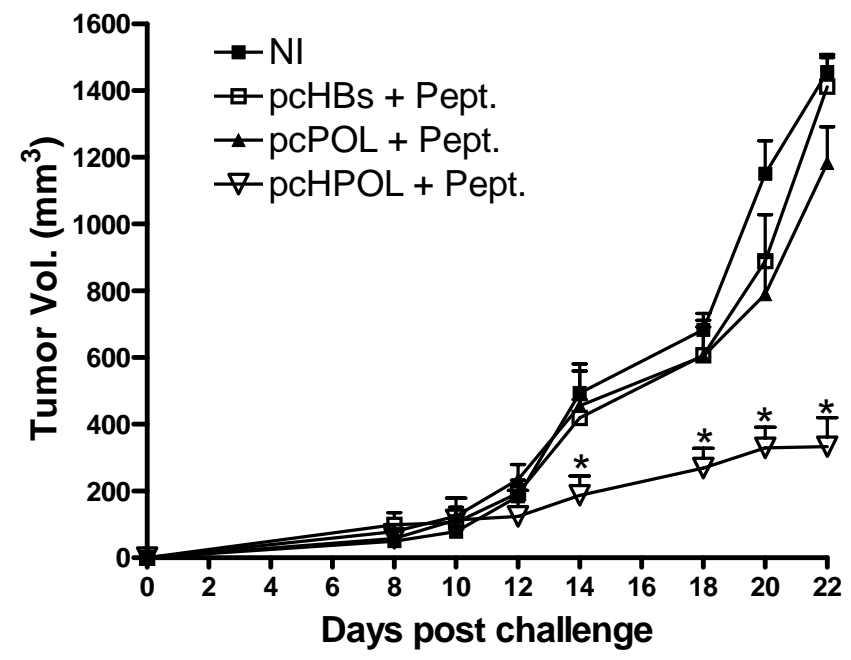


Table. Immunization regimens, groups of vaccinated animals and the employed immunoassaying methods corresponding to each immunized mice group.

\begin{tabular}{|c|c|c|}
\hline $\begin{array}{l}\text { Immunization } \\
\text { Regimens }\end{array}$ & $\begin{array}{c}\text { Vaccinated Groups } \\
\text { (based on immunogen) }\end{array}$ & Assaying Methods \\
\hline \multirow{4}{*}{$\mathrm{DNA} \times 3^{\mathrm{a}}$} & pcPOL & CTL, IFN $\gamma$ ELISpot \\
\hline & pcHPOL & CTL, IFN $\gamma$ ELISpot, Cytokine release \\
\hline & pcDNA3.1 & CTL, IFN $\gamma$ ELISpot \\
\hline & pcHBs & CTL, IFN $\gamma$ ELISpot \\
\hline \multirow{3}{*}{$\begin{array}{c}\text { DNA } \times 2^{\mathrm{a}} \\
\text { Peptide } \times 1^{\mathrm{a}}\end{array}$} & pcPOL-CE $\mathrm{CE}_{6} \mathrm{~N}$ & Tumor challenge \\
\hline & pcHPOL-CE $E_{4} E_{6} \mathrm{~N}$ & IFN $\gamma$ ELISpot, Cytokine release,Tumor challenge \\
\hline & pcHBs-CE $\mathrm{E}_{6} \mathrm{~N}$ & Tumor challenge \\
\hline Peptide $\times 3^{\mathrm{a}}$ & $\mathrm{CE}_{4} \mathrm{E}_{6} \mathrm{~N}$ & IFN $\gamma$ ELISpot, Cytokine release \\
\hline
\end{tabular}

${ }^{\mathrm{a}}$ Times of the vaccination by immunogen prior to immunologic assays. 